\title{
PEDAGOGICAL STRATEGIES FOR THE FORMATION OF CULTURAL IMMUNITY IN ADOLESCENT SCHOOLCHILDREN
}

\section{Tojiboeva Xilolakhon Makhmutovna}

Senior Researcher, Doctor Of The Scientific Research Institute Of Pedagogical Sciences Of Uzbekistan, Doctor Of Philosophy In Pedagogical Sciences (Phd)

\section{ABSTRACT}

This article analyzes the pedagogical strategies for the formation of immunity against "popular culture" in adolescents, and highlights the pedagogical possibilities of introducing adolescents to the peculiarities of popular culture.

KEYWORDS: - Popular culture, hybrid culture, national culture, adolescent students, pedagogical strategies, social roles, pedagogical opportunities, contradictions, norms of behavior, stereotypes.

\section{INTRODUCTION}

Globalism as a mixture of characters characteristic of different cultures around the world, a hybrid culture arose. This in turn, young people of this culture, especially the teenage age, gained consciousness, they began to have a double (positive and negative) impact on the behavior and cultural outlook. The dual influence of mass culture has laid the foundation for the formation of non-destructive stereotypes and behaviors that are not characteristic of gender roles in the behavior of adolescent students.

\section{LITERATURE ANALYSIS AND METHODOLOGY}

Theories of dolinashvlarning analysis of shunikarakatdiki [1-2], globalshuv thanks to vizhudge kelgan culture kulturular krillar turli milatlona bulgan culture karashlar, kadrijlar, cultural boilar, aallar and urf-odatlar, gender culture culture of denial kilybi, yzining kruifodi mausudi bulagon culture of recognition etib, joshlar ainoixa ysmerllar ongi Singh kladirishga karatilgan Promotions volavorini kublashga kiletganliga movement is definitely noticeable bulmokda.

The pedagogical Encyclopedia is interpreted in the style of " pedagogical strategy - a long-term program of basic actions aimed at achieving clearly defined goals in the field of education and pedagogy" [3; p 49].

\section{RESEARCH METHODOLOGY}

In this article, a systematic approach and analytical methods were used to describe the 
CURRENT RESEARCH JOURNAL OF PEDAGOGICS 2(11): 215-219,

November 2021 DOI: https://doi.org/10.37547/pedagogics-crjp-02-11-39

ISSN 2767-3278

(C)2021 Master Journals

Crossref do) 81 Google

Accepted 25th November, 2021 \& Published 30 ${ }^{\text {th }}$ November, 2021

pedagogical strategies for the formation of an immune response to "mass culture"in adolescent schoolchildren, the pedagogical opportunities to acquaint students with the peculiarities of mass culture.

\section{AnAlysis AND RESUlts}

Pedagogical strategies focus the attention of the educator on the educational goal. The interaction of the educator with the pupils as a result of his professional activity, ensures their influence. The final result of pedagogical activity is the formation of an immunity to mass culture in adolescent schoolchildren within the framework of our study. And pedagogical strategies ensure that the teacher achieves the goal in a strict, stable manner. Bunda is manifested in the ability to interpret events, actions, facts and random employees within the framework of the purpose of pedagogical education.

Within the pedagogical goal, the teacher with the help of certain strategies affects the students of adolescent age. If egoistic actions are prioritized in the mood of adolescent students, the teacher seeks a solution to the problem with the help of certain strategies in the interest of them.

One of such strategies is the strategy that will serve the readers to find out how their friends are and to get their attention.

Teachers with strategic thinking can clearly imagine the main goal of Education. These are strategies that have a common vision: to evaluate the individual manifestations inherent in the educational processes, to take into account the specific differences inherent in the personality of the bunda, not to ignore such situations as irritability, aggressiveness, which are present in the behavior of adolescent boys, does not carry out strict control based on the rigor that is unusual for the At the same time, it does not take into account aspects that are alien to the life of adolescents, affecting their maturity.
The negative impact of mass culture on adolescents is one of the similar aspects. Because the negative impact of mass culture on the fate of adolescents can have its own non-destructive effect. Pedagogical calm is one of the external manifestations of the strategy. For example, students of adolescent age can ask them not to be angry with the educator when they openly admit that they did not fulfill the tasks, that it was possible to do the same job in a calm manner, emphasize the need for them to perform this task until the next training session, and punish the students in a specific way by

From the point of view of pedagogical strategy, it ensures the manifestation of a mature personality in the minds of students. The fact that the teacher has a pedagogical strategy and tactics ensures that social cultural norms are easily integrated into the minds of students.

The game strategy is of particular importance in the formation of an immune response to mass culture in adolescent schoolchildren. Particular attention should be paid to problematic-active game strategies. We have initially made use of the strategy of interpersonal relationship problems and solutions. Bunda also drew attention to the relationship between teenage girls and boys.

The purpose of the game: to identify the conflict and the reasons that make it come out, to look for ways to eliminate the conflicts that arise during the interaction, to identify measures to improve the relationship between the class and the team.

The content of the exercise Conflict nets exercise. Today, the problem of communication between adolescents, especially teenage boys and girls, has become extremely urgent. It is known that until now, the measures of communication and its improvement between a boy and a girl in adolescence have not been specially studied. Communication between teenage boys and girls, 
CURRENT RESEARCH JOURNAL OF PEDAGOGICS 2(11): 215-219,

November 2021 DOI: https://doi.org/10.37547/pedagogics-crjp-02-11-39

ISSN 2767-3278

(C)2021 Master Journals

Crossref do) 81 Google

Accepted 25th November, 2021 \& Published 30 ${ }^{\text {th }}$ November, 2021

which is a component of personality relationships, has become more strained in the influence of mass culture. This is especially evident in the interaction of adolescents. Literate communication gives the opportunity to overcome difficulties between the class team. Therefore, the improvement of mutual relations between adolescents directly and indirectly contributes to the establishment of interpersonal relations. Conflicts are inherent in human nature, which is more common, especially among adolescents. Because the behavior of teenage girls, which is not characteristic of our mentality, especially the style of dressing, the culture of treatment, it seems to be melting to teenage boys. It is becoming the main cause of conflicts between them. The problematic-active game strategy we offer is aimed at building interpersonal relationships between adolescent students. Within the framework of this strategy, the reasons for the conflict, the reasons for it, the ways of partitioning the conflict are proposed. Measures to improve the personlararo relationship are determined.

In the middle of the whiteboard, a conflict question is written and taken to the circle. Students who are participants in the training will be assigned the task of determining the connection between the words in the circle. The following questions are asked to the readers: how can we determine the conflict? What do we have in common between the contradictions identified by us? What brings out the contradictions and what actions complicate it? What sharpens the conflicts and helps to solve them? What are the main reasons for the conflict coming out?

Experts say that conflicts can be constructive, destructive and simply simple. What do they differ among themselves? Give examples from your own life. Indicate the peculiarities of establishing a successful relationship and an important condition for showing the appearance of behavior in relation to the surrounding people. They emphasize that informing participants about the negative aspects of their character, demonstrating their negative behavior is the main reason for their rudeness, unwillingness to engage in work, putting people against each other mutually. In this way, conflicting situations arise and a solution is sought for it.

2 . Work in a group. Each group is presented with a set of conflicting situations. Students in the group analyze it, indicate the causes of the conflict and indicate the reasons for the described reality. A representative of each group presents the results of his work. In the process of discussion, the leader of the group leaves records on the blackboard. At the end of the work, the information on the causes of the violation of relations between the parties and the Huluauthor's strategy is summarized, its causes are indicated.

The reasons for the violation of relations are manifested in the following: 1 . Inadequate form of communicative competence in the members of the group, unwillingness to take into account the individual characteristics of the individual or inadequate form of skills in this direction, indifference to the feelings of the groupmate or disregard for his or her livelihood; intolerance to criticism, distrust of the surrounding people, manifestation of rudeness, lack of a culture of treatment; low level of upbringing; ; it is like the form of the ability to control one's own emotions, the lower the level of empathy, the inability to adequately perceive oneself and their group mates.

3. Diagnostic strategy of individual behavior in conflict situations. K.Thomas proposed a twosided model of the Holocaust diagnostic strategy in conflict situations [4]. Bunda takes a masterful role in the strategy of focusing the attention of the individual on others. Teaching adolescents to use strategies to protect their personal interests 
CURRENT RESEARCH JOURNAL OF PEDAGOGICS 2(11): 215-219,

November 2021 DOI: https://doi.org/10.37547/pedagogics-crjp-02-11-39

ISSN 2767-3278

(C)2021 Master Journals

Crossref do: 81 Google

Accepted 25th November, 2021 \& Published 30 ${ }^{\text {th }}$ November, 2021

by engaging in conflict situations is important in shaping the immune response to mass culture in them. 5 effective strategies for managing conflict situations are recognized by the majority of specialists: competition, cooperation, mutual agreement, avoidance, adaptation strategies.

Among the members of the group there is an opportunity to establish these relations using a certain strategy in case of violation of individual relations.

4. Strategy for the analysis of the behavior of a teenage schoolboy. This strategy has its drawbacks and advantage aspects. Each small group is assigned the task of determining one of the manifestations of Hulu. The positive and negative aspects of each strategy are shown on the basis of the analysis. Competition (competition) ensures the achievement of the expected result by harming others by acting in their own interests. Each person protects his point of view to the end. He does not want to swallow. Therefore, such people are always right. Whoever chooses the strategy of competition will carry it out as follows: they will try to prove the dishonesty of others; they will be offended until they think about it; in some cases they will go until the use of force; they will demand from their peers that they listen to it unconditionally; they will not accept refuting thoughts; they will call on their supporters to.

The style of competition is able to keep strongwilled owners strong. For this, they are considered necessary cultural immunity. Adolescents with strong will and reputation do not need to build relationships with others, compete. They strive to satisfy their personal curiosity. They use it in the following cases: for adolescents, the origin of the conflict is important, they try to solve their problems; for adolescents with sufficient reputation in their community, they believe in the correctness of the proposed solutions; they feel that in some cases there is little chance of choice, they have nothing to lose, in such situations, adolescents become capricious, aggressive; adolescents need to choose specific solutions, take an important step. This in turn serves to stabilize the interpersonal relationship between the members of the group [5; p 92].

Conflicts and the global impact of mass culture have been the hallmarks of mutual alienation in adolescents.

And the consensus strategy is that adolescent schoolchildren give each other a side and create the opportunity to establish individual relationships. The main essence of this strategy is to promote the stabilization of interpersonal relations by the mutual agreement of both parties entering into conflict. In this sense, collaboration strategies also ensure that the parties side by side. The implementation of consensus chtrategies is manifested in the following: support of friendly relations; truthful solution izlash; equal sharing of the desired subject; to forget about his rule and respect the interests of his partner; to himself is also to acquire nimanilir; to avoid direct conflicts; to establish relations with the purpose of support.

This strategy is considered effective if both parties try to stabilize the relationship. When applying this strategy, attention is paid to the search for its options, and not the solution that satisfies both parties. These options are expressed through the following words: we can not fully fulfill our desire, each of us will try to accept a solution that will be a role. Such an approach to conflict resolution is considered effective in the following situations: when both parties have the same arguments; when the realization of one side's desire is not of great importance to him; when a particular solution temporarily satisfies the subject of the relationship, when there are no other effective solutions in this process. 
CURRENT RESEARCH JOURNAL OF PEDAGOGICS 2(11): 215-219,

November 2021 DOI: https://doi.org/10.37547/pedagogics-crjp-02-11-39

ISSN 2767-3278

(C)2021 Master Journals

Crossref do: 81 Google

Accepted 25th November, 2021 \& Published 30 ${ }^{\text {th }}$ November, 2021

Adaptation strategies require adaptation to the situation, even if it itself is damaged by pursuing second-party strategies. Such adolescents punish their opponents with compassion, tolerance. They insist on the point of their opponents and give up their own interests. The implementation of such an approach in the individual relationship is characteristic of the national mentality of the Uzbek people, serves to establish individual relations in the group and promotes the formation of cultural immunity in adolescents [6].

Forms of conciliation strategy especially the conciliation is clearly manifested in the following cases: in bunda the adolescent schoolboy will behave in the place of all his affairs, will continue to move as if nothing had happened, will be able to withstand the situations that have arisen in order not to break the calmness, especially to use attractiveness to achieve the necessary goal;

\section{Conclusions And SugGestions}

In general, the use of a number of strategies in the formation of an immune response to mass culture on the basis of a gender approach in adolescent schoolchildren, such as play, reconciliation, cooperation, deviations, concessions, ensuring the success of the pedagogical process, the realization of the essence of gender-specific roles in adolescents, the establishment of individual relations, the acquisition of cultural communication skills, , making the right decisions in conflict situations contributes to the formation and stable manifestation of cultural moral qualities, such as intolerance to foreign ideas.

\section{ReFERENCES}

1. Safarova R.G. and b. Reader-pedagogicalpsychological links of the formation of skills of struggle against "mass culture"in young people. - Monograph. - T.: "Wing of thought" publishing house, 2018 year, 192 page.

2. Tojiboeva X.M. Strategies for the formation and development of skills structling for "mass culture" in the subjects of continuing education// journal of critical reviews. ISSN-2394-5125. val 7, ISSUE 19, 2020. P.4018-4022.

3. Pedagogy: encyclopedia. Volume III. team / / Tashkent: State Scientific Publishing House "National Encyclopedia of Uzbekistan", 2017. 424-bet. B.49

4. https://www.sites.google.com/site/skazik onfliktamnet/strategii-povedenia-vkonflikte-k-tomasa

5. Gaziev E. Psychology: psychology of young periods: a study guide for students of pedagogical institutes and universities / E. Gaziev. - Tashkent: Teacher, 1994. - 223 P.

6. Tojiboeva X.M. Pedagogical foundations of the development of a socially active personality //Theory and practice of education in the modern world. - 2012. pp. 26-28. 